\title{
Palmo-plantar hyperkeratosis associated with HTLV-1 infection: a case report
}

\author{
Elías Quintero-Muñoz ${ }^{1}$, Daniel Martin Arsanios², María Fernanda Estupiñán Beltrán² ${ }^{*}$, Juan David Vera ${ }^{3}$, \\ Catalina Palacio Giraldo ${ }^{1}$, Omar Velandia ${ }^{3}$ and Carlos Mauricio Calderon ${ }^{3}$
}

\begin{abstract}
Background: Palmoplantar hyperkeratosis is a cutaneous manifestation that had not been clearly associated with infection by the human T-cell lymphotropic virus, which is a retrovirus that in most cases does not develop clinical pathologies and its symptoms may be undetected. The skin is one of the most affected organs, however until now only seborrheic dermatitis, xerosis/ichthyosis and infective dermatitis associated with HTLV-1 have been described as cutaneous clinical manifestations of this disease.
\end{abstract}

Case presentation: We present the case of a 36-year-old male patient with serologically documented HTLV-1 infection, who presented symptoms of diarrhea, malabsorption due to Strongyloides stercoralis, and in whom a physical examination revealed an association with generalized xerosis and palmoplantar keratoderma confirmed by skin biopsy. Other infectious etiologies and malignancy were ruled out. This clinical manifestation was managed with dermal hydration, and skin care which improved the thickened skin and make it less noticeable.

Conclusions: According to our experience, this is the first reported case of palmoplantar keratoderma associated with a human lymphotropic virus infection. This is a skin manifestation that has not been confirmed in conjunction with HTLV-I before. This implies that palmoplantar keratoderma is a new clinical manifestation of this infection, that should be considered in the initial approach of patients in endemic areas with these dermatological characteristics.

Keywords: HTLV, Palmoplantar keratoderma, Strongyloides stercoralis, Malabsortive diarrhea, Case report

\section{Background}

Human T-cell Lymphotropic Virus (HTLV) is a retrovirus first isolated in 1980 from a T lymphocyte in a patient with cutaneous lymphoma (HTLV-1), after that, HTLV-2 was identified in cells from a patient with hairy cell leukemia $[1,2]$. Despite the fact that most HTLV-1 infections are usually asymptomatic, in some cases it has been associated with multiple pathologies that produce high morbidity and mortality, such as Adult T-cell Leukemia/Lymphoma (ATLL), Myelopathy / Tropical Spastic Paraparesis (TSP) and a wide spectrum of skin involvement, the skin being one of the organs most

\footnotetext{
* Correspondence: mariafernandaeb@gmail.com

${ }^{2}$ Internal Medicine resident, La Sabana University, Chía, Colombia

Full list of author information is available at the end of the article
}

affected by this virus [3-6]. HTLV-2 infection, has not been consistently related to any pathology, there are few case reports that relate it to neurological diseases [7].

HTLV-1 infection is endemic in southern Japan, the Caribbean, Central and South America, some regions of Africa, also Australia and the Pacific [8]. The development of clinical pathologies is rare and only $3-5 \%$ of carriers manifest them; this situation depends on the age, time of infection and immune system state [9]. The wide range of manifestations may be due to virusdependent cellular transformation or alterations generated on the immune status of the host [10].

Palmoplantar keratodermas (PPK) are a heterogeneous group of keratinization disorders with hyperkeratotic thickening of palms and soles. The etiology can be hereditary, caused by mutations in genes that encode

(C) The Author(s). 2021 Open Access This article is licensed under a Creative Commons Attribution 4.0 International License, which permits use, sharing, adaptation, distribution and reproduction in any medium or format, as long as you give appropriate credit to the original author(s) and the source, provide a link to the Creative Commons licence, and indicate if changes were made. The images or other third party material in this article are included in the article's Creative Commons licence, unless indicated otherwise in a credit line to the material. If material is not included in the article's Creative Commons licence and your intended use is not permitted by statutory regulation or exceeds the permitted use, you will need to obtain permission directly from the copyright holder. To view a copy of this licence, visit http://creativecommons.org/licenses/by/4.0/ The Creative Commons Public Domain Dedication waiver (http://creativecommons.org/publicdomain/zero/1.0/) applies to the data made available in this article, unless otherwise stated in a credit line to the data. 
proteins that are components of the intracellular cytoskeleton such as keratin or that participate in intercellular adhesion, cell-to-cell communication (for example, Connexins) and cell signaling. The other group of PPK are acquiredes which are secondary to toxic, infectious diseases and malignant neoplasms including esophageal cancer, Hodgkin's disease, prolymphocytic leukemia, renal, mammary, pancreatic, colonic adenocarcinomas and malignant melanoma [11].

We present the case of a patient with serologically documented HTLV infection associated with acquired palmoplantar keratoderma transgrediens, a cutaneous manifestation of HTLV not clearly described in the literature, also in the context of an adult patient with malabsorptive diarrhea and Strongyloides stercoralis infection.

\section{Case presentation}

A 36-year-old male patient, from Valle del Cauca, Colombia, incarcerated in a penitentiary center, without medical or family history, who was admitted to the emergency department due to a 3-month clinical course consisting of liquid stool, approximately 7 episodes daily, associated with multiple emetic episodes of food content and weight loss. In addition, patient reported an 8month history of palmoplantar hyperkeratosis with onychrygriphosis and generalized cutaneous xerosis (Fig. 1), without treatment. Apart from skin lesions, no other relevant findings of the physical examination were found.

Among the laboratory studies carried out, the presence of positive serology for HTLV-1 and other negative infectious studies stands out. To rule out malignancy, bone marrow studies were performed, including biopsy, which had no evidence of malignancy (Table 1). A total abdominal ultrasound was also performed, which ruled out the presence of abdominal masses including renal masses. A colonoscopy was performed that only reported external hemorrhoids without mass findings. Diarrheal disease with malabsorption characteristics was considered and rifaximin treatment was started $(200 \mathrm{mg}$ three times a day for 3 days), however, it did not have an adequate response to treatment; Subsequently, an endoscopy of the upper digestive tract was performed with a finding of erosive bulbooduodenitis with a biopsy that revealed abundant forms of Strongyloides stercoralis, so treatment with ivermectin was started $(200 \mathrm{mcg} / \mathrm{kg} /$ dose), with the consequent decrease in the frequency and volume of bowel movements.

It was decided to manage with dermal hydration and skin care, including emollients, as part of the treatment of PPK, which was confirmed by skin biopsy (Fig. 2). The PPK was thought to be related to HTLV-1, due to the wide spectrum of cutaneous manifestation that the infection can cause, although, this association has not been previously reported.

\section{Discussion/conclusion}

Although HTLV-1 infection in most cases does not generate disease, it has been described that many of these patients are not entirely asymptomatic and are compromised undetected, the skin is one of the most affected organs, as evidenced by the series of cases in the blood donors $[6,12]$. This fact becomes more important since our territory is recognized as an endemic area, with epidemiological data corresponding to a prevalence between $0.17-0.3 \%$, the most affected regions are the Pacific, Caribbean and Andean region [13, 14].

Among the characteristic cutaneous manifestations directly related to infection by HTLV-1 are infectious
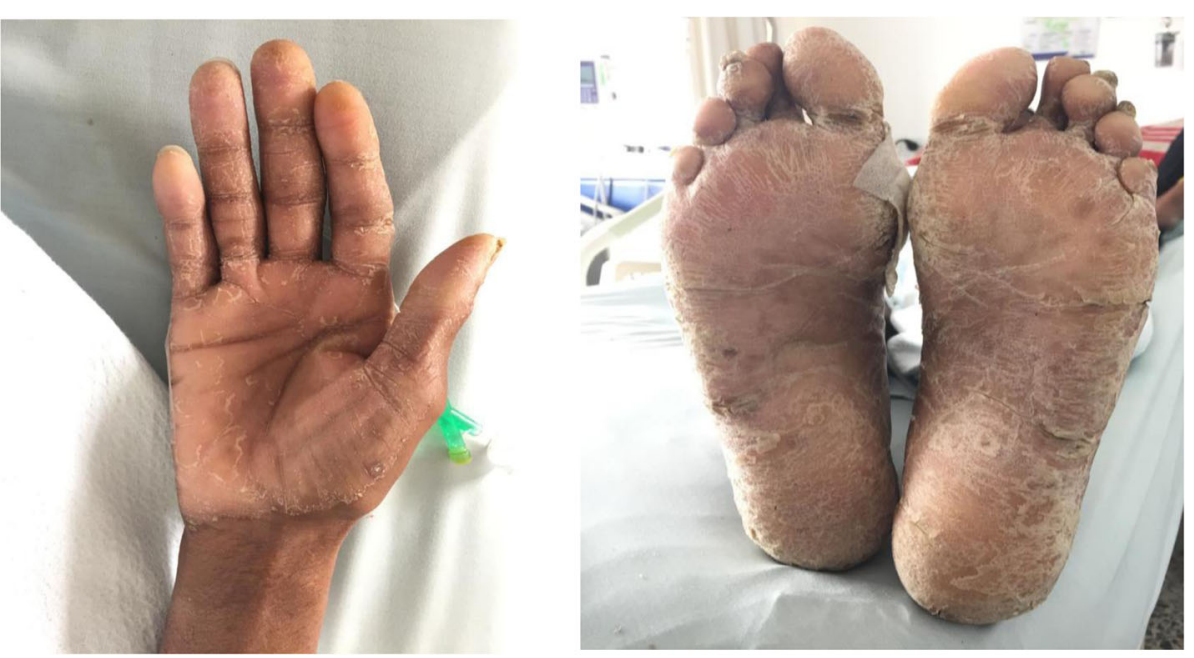

Fig. 1 Palmoplantar hyperkeratosic lesions and xerosis. (a) Palms (b) plant 
Table 1 Laboratory results

\begin{tabular}{|c|c|c|c|c|c|}
\hline \multicolumn{2}{|l|}{ Blood count } & \multicolumn{2}{|c|}{ Infectious profile } & \multirow{3}{*}{$\begin{array}{l}\text { Coproscopic } \\
\text { No parasitic structures are } \\
\text { observed in the analyzed } \\
\text { sample }\end{array}$} & \multirow{4}{*}{$\begin{array}{l}\text { Bone marrow studies } \\
\text { Peripheral blood smear: Normal white blood cells in number and } \\
\text { morphology neutrophils: } 69 \% \text { lymphocytes: } 20 \% \text { monocytes: } 10 \% \\
\text { Eosinophils: } 1 \% \text {. Red blood cell morphology with mild anisocytosis and } \\
\text { hypochromia. Increased platelet count and occasional macro platelets. } \\
\text { Conclusion: } \\
\text { Morphological abnormalities in lymphocytes with a cleaved nucleus, } \\
\text { associated with neutrophilia with evidence of Pelger Hüet abnormality } \\
\text { and significant thrombocytosis }\end{array}$} \\
\hline $\begin{array}{l}\text { Leukocytes } \\
\left(\text { cell/mm } / \mathrm{mm}^{3}\right)\end{array}$ & $\begin{array}{l}10, \\
170\end{array}$ & HIV & Negative & & \\
\hline $\begin{array}{l}\text { Neutrophils } \\
\left(\text { cell/mm } / \mathrm{mm}^{3}\right)\end{array}$ & 5340 & $\begin{array}{l}\text { Non- } \\
\text { treponemal } \\
\text { test }\end{array}$ & $\begin{array}{l}\text { No } \\
\text { reactive }\end{array}$ & & \\
\hline $\begin{array}{l}\text { Lymphocytes } \\
\left(\text { cell/ } / \mathrm{mm}^{3}\right)\end{array}$ & 3620 & $\mathrm{HBsAg}$ & Negative & & \\
\hline $\begin{array}{l}\text { Monocytes } \\
\left(\text { cell//mm } \mathrm{mm}^{3}\right)\end{array}$ & 1110 & $\begin{array}{l}\text { HTLV } \\
\text { serology }\end{array}$ & $\begin{array}{l}80.33 \\
\text { (Positive) }\end{array}$ & & $\begin{array}{l}\text { Bone marrow biopsy: Hypocellular bone marrow for age with } \\
\text { alteration in the myeloid and megakaryocytic lines. }\end{array}$ \\
\hline $\begin{array}{l}\text { Eosinophils } \\
\left(\text { cell/mm } / \mathrm{mm}^{3}\right)\end{array}$ & 104 & & & & \\
\hline $\begin{array}{l}\text { Haemoglobin } \\
(\mathrm{g} / \mathrm{dl})\end{array}$ & 13 & & & & \\
\hline $\begin{array}{l}\text { Haematocrito } \\
(\%)\end{array}$ & 38.5 & & & & \\
\hline $\begin{array}{l}\text { Platelets (cell/ } \\
\mathrm{mm}^{3} \text { ) }\end{array}$ & $\begin{array}{l}559 \\
000\end{array}$ & & & & \\
\hline
\end{tabular}

dermatitis, crusted scabies, and skin injuries by ATLL and MPET [12, 15, 16]. According to a series of cases with more patients, in a population of Brazil, they evidenced a prevalence of skin alteration in asymptomatic seropositive patients of $76 \%$ and in those with MPET it was $88 \%$. Among the findings, inflammatory pathologies predominated, acquired xerosis/ichthyosis and seborrheic dermatitis were the most frequent skin disorders in the adult population, with a prevalence of $60.2 / 42.5 \%$ (xerosis / ichthyosis) and $47.9 / 15 \%$ (seborrheic dermatitis) for the asymptomatic and MPET groups respectively; likewise, infectious diseases obtained a prevalence of $30 \%$, with dermatophytosis and scabies being the most prevalent [17]. On the other hand, infectious dermatitis prevails in the child population, who are characterized by presenting generalized eczema and Staphylococcus and Streptococcus infections who require chronic antibiotic treatment because of high recurrence rate $[4,5,18]$. In 1993, Nagatani, et al. published a case report showing a possible association



Fig. 2 Skin biopsy between PPK and HTLV-1, but a definitive diagnosis was not confirmed by biopsy [19].

Our case is relevant because it presents a cutaneous manifestation, confirmed by biopsy, which has not been described in association with HTLV-1 infection, it presents generalized cutaneous xerosis associated with PPK transgrediens, which is a condition consisting of the abnormal thickening of the epidermis of palms and plants, and additionally has the ability to affect areas beyond the palmoplantar skin, these qualities differentiate it from acquired ichthyosis, since it does not meet the clinical characteristics of the adherent visible scales, nor the alteration in the granular layer, which are documented structural characteristics in the biopsy; therefore, this pathology is ruled out.

PPK is considered an independent clinical entity that is part of the palmoplantar keratoderma group and the approach of the etiology requires the assessment of multiple systemic and non-systemic conditions that may be associated with its presentation, including infectious, malignancy, endocrine and autoimmune diseases, among others. PPK has been associated with perimenopause, the use of drugs, or infectious processes such as dermatophytosis, human papilloma virus, syphilis, leprosy, miliary tuberculosis, and scabies (ruled out pathologies in the case report) but never with HTLV [20]. Particularly, PPK secondary to human papilloma virus is especially presented in immunocompromised patients and the usual presentation is confluent verrucous masses on the palms and soles. Our case is about a patient without laboratory alterations suggesting compromise in the immune system, similarly, skin demonstrations were not the usual reported for this infection. Our experience suggests that PPK is a newly recognised cutaneous manifestation associated with HTLV-1 infection. 
Furthermore, the association between HTLV-1 infection and Strongyloides stercolaris is known. The available evidence suggest HTLV-1 infection is more frequently associated (up to 2.4 times more) with Strongyloides stercolaris infection [21, 22]. Similarly, it has been suggested that Strongyloidiasis increases the risk of diseases associated with HTLV-1, modifying its viral load [23], a view that this coinfection is considered a possible risk factor for the development of lymphoproliferative syndromes associated with this virus, or even serve as a marker of severity of HTLV-1 infection [22]. Strongyloides hyperinfection syndrome, is a severe form of strongyloidiasis, has been described in patients with drug immunosuppression or secondary to malignancy, but also in cases of HTLV-1 infection [24]. Although strongyloidiasis has been associated with malabsorption syndromes, there is no clear association in literature suggesting a relationship between PPK and malabsorption syndromes of another etiology. This case is about a patient who had no clinical or paraclinical demonstration suggesting any particular systemic condition.

According to that, the evaluation of this coinfection and this cutaneous manifestation not previously described in relation to HTLV-1 infection, is important in order to carry out an adequate evaluation and follow-up, monitoring the possible progression of the disease and the development of complications to short and long term in an endemic region.

\section{Abbreviations}

HTLV: Human T-cell Lymphotropic Virus; ATLL: Adult T-cell Leukemia/Lymphoma; TSP: Myelopathy / tropical spastic paraparesis; PPK: Palmoplantar Keratoderma

\section{Acknowledgements}

Not applicable.

\section{Authors' contributions}

EQM, DMA and JDV did the literature search and drafted the manuscript. MFE contributed to writing, review and editing. CPG writing and took the photographs of the patient and histopathology. OV and CMC conceived the case report and provided guidance for drafting the manuscript. All authors read and approved the final manuscript.

\section{Funding}

No funding was obtained for this study.

\section{Availability of data and materials}

All data and materials of this article are included in the manuscript.

\section{Declarations}

Ethics approval and consent to participate

Not applicable.

\section{Consent for publication}

Written informed consent was obtained from the patient for the publication of this case report and the accompanying images. A copy of the written consent is available for review by the Editor-in-Chief of this journal.

\section{Competing interests}

The authors did not receive any research support for this manuscript. The authors declare that they have no competing interests.

\section{Author details}

${ }^{1}$ General Medicine, La Sabana University, Chía, Colombia. ${ }^{2}$ Internal Medicine resident, La Sabana University, Chía, Colombia. ${ }^{3}$ Internal Medicine, La Samaritana Hospital, Bogotá, Colombia.

Received: 27 April 2020 Accepted: 17 June 2021

Published online: 06 July 2021

\section{References}

1. Poiesz BJ, Ruscetti FW, Gazdar AF, Bunn PA, Minna JD, Gallo RC. Detection and isolation of type $C$ retrovirus particles from fresh and cultured lymphocytes of a patient with cutaneous T-cell lymphoma. Proc Natl Acad Sci U S A. 1980;77(12 II):7415-9.

2. Bittencourt $A L$, de FP de Oliveira M. Cutaneous manifestations associated with HTLV-1 infection. Int J Dermatol. 2010;49(10):1099-110. https://doi. org/10.1111/j.1365-4632.2010.04568.x.

3. Caskey MF, Morgan DJ, Porto AF, Giozza SP, Muniz AL, Orge GO, et al. Clinical manifestations associated with HTLV type I infection: a crosssectional study. AIDS Res Hum Retrovir. 2007 Mar;23(3):365-71. https://doi. org/10.1089/aid.2006.0140

4. Dantas L, Netto E, Glesby M, Carvalho E, Machado P. Dermatological manifestations of individuals infected with human T-cell Lymphotropic virus type 1. Int J Dermatol. 2014;53(9):1098-102. https://doi.org/10.1111/ijd.121 70.

5. Nobre V, Guedes AC, Martins ML, Barbosa-Stancioli EF, Serufo JC, Proietti FA, et al. Dermatological findings in 3 generations of a family with a high prevalence of human T cell Lymphotropic virus type 1 infection in Brazil. Clin Infect Dis. 2006;43(10):1257-63. https://doi.org/10.1086/508177.

6. Utsch Gonçalves D, Martins Guedes AC, Carneiro Proietti ABDF, Lobato Martins M, Proietti FA, Lambertucci JR. Dermatologic lesions in asymptomatic blood donors seropositive for human T cell lymphotropic virus type-1. Am J Trop Med Hyg. 2003;68(5):562-5. https://doi.org/10.42 69/ajtmh.2003.68.562.

7. Panfil AR, Green PL. HTLV-1 and HTLV-2. Ref Modul Life Sci. 2020 Jan 1; (Elsevier).

8. Catalan-Soares B, Carneiro-Proietti AB de F, Proietti FA. Heterogeneous geographic distribution of human T-cell lymphotropic viruses I and II (HTLVI/II): serological screening prevalence rates in blood donors from large urban areas in Brazil. Cad saúde pública / Ministério da Saúde, Fundação Oswaldo Cruz, Esc Nac Saúde Pública. 2005;21(3):926-31. https://doi.org/10.1 590/S0102-311X2005000300027.

9. Gessain A, Cassar O. Epidemiological aspects and world distribution of HTLV-1 infection. Front Microbiol. 2012;3:388-9.

10. Yamano Y, Sato T. Clinical pathophysiology of human T-lymphotropic virustype 1-associated myelopathy/tropical spastic paraparesis. Front Microbiol. 2012:3:385-89.

11. Has C, Technau-Hafsi K. Palmoplantar keratodermas: clinical and genetic aspects. J der Dtsch Dermatologischen Gesellschaft. 2016;14(2):123-40.

12. García-Huidobro I, Cárdenas C, Molgó M, González S. Manifestaciones cutáneas en donantes de sangre portadores de HTLV-1 en comparación con donantes de sangre no portadores de HTLV-1. Rev Med Chil. 2014; 142(7):859-66. https://doi.org/10.4067/S0034-98872014000700006.

13. Antonio Cardona-Arias JI, Vé lez-Quintero C, Victoria Calle-Gonzá lez O, Florez-Duque J, Carlos Zapata J. Seroprevalence of human T-lymphotropic virus HTLV and its associated factors in donors of a blood bank of MedellínColombia, 2014-2018. 2014;14(8).

14. Bermúdez-Forero MI, Berrío-Pérez M, Herrera-Hernández AM, RodríguezRodríguez MJ, García-Blanco S, Orjuela-Falla G, et al. Prevalencia de la infección con el virus linfotrópico de células T humanas de tipo 1 y 2 en donantes de sangre en Colombia, 2001-2014: Implicaciones sobre la seguridad de la transfusión. Biomedica. 2016;36:194-200. https://doi.org/10. 7705/biomedica.v36i0.2943

15. Lenzi MER, Cuzzi-Maya T, Oliveira ALA, Andrada-Serpa MJ, Araujo AQ-C. Dermatological findings of human T Lymphotropic virus type 1 (HTLV-I)associated myelopathy/tropical spastic Paraparesis. Clin Infect Dis. 2003; 36(4):507-13. https://doi.org/10.1086/367572. 
16. Javad Yazdanpanah M, Maleki M, Joneidi N, Reza Khalighi A, Reza Azarpazhooh M, Khajedaluee M, et al. Cutaneous manifestations in HTLV-I positive blood donors. Iran J Basic Med Sci. 2013;16(3):273-7.

17. Okajima R, Oliveira ACP, Smid J, Casseb J, Sanches JA. High prevalence of skin disorders among HTLV-1 infected individuals independent of clinical status. PLoS Negl Trop Dis. 2013;7(11):1-5.

18. Amano M, Setoyama M, Grant A, Kerdel FA. Human T-lymphotropic virus 1 (HTLV-1) infection - dermatological implications. Int J Dermatol. 2011;50(8): 915-20. https://doi.org/10.1111/j.1365-4632.2011.04882.x.

19. Nagatani T, Miyazawa M, Matsuzaki T, lemoto G, Kim S, Baba N, et al. Successful treatment of adult T-cell leukemia/lymphoma with MACOP-B, MFEPA and VEPP-B combination chemotherapy. J Dermatol. 1993 Oct 1 20(10):623-9. https://doi.org/10.1111/j.1346-8138.1993.tb01351.x.

20. Patel S, Zirwas M, English JC. Acquired palmoplantar keratoderma. Am J Clin Dermatol. 2007;8(1):1-11. https://doi.org/10.2165/00128071-20070801000001.

21. Robinson RD, Lindo JF, Neva FA, Gam AA, Vogel P, Terry SI, et al. Immunoepidemiologic studies of strongyloides stercoralis and human $t$ lymphotropic virus type i infections in Jamaica. J Infect Dis. 1994;169(3):6926. https://doi.org/10.1093/infdis/169.3.692.

22. Tanaka T, Hirata T, Parrott G, Higashiarakawa M, Kinjo T, Kinjo T, et al. Relationship among strongyloides stercoralis infection, human T-cell lymphotropic virus type 1 infection, and cancer: a 24-year cohort inpatient study in Okinawa, Japan. Am J Trop Med Hyg. 2016;94(2):365-70. https:// doi.org/10.4269/ajtmh.15-0556.

23. Gillet NA, Cook L, Laydon DJ, Hela C, Verdonck K, Alvarez C, et al. Strongyloidiasis and Infective Dermatitis Alter Human T Lymphotropic Virus1 Clonality in vivo. PLoS Pathog. 2013;9(4):7-9.

24. Gotuzzo E, Terashima A, Alvarez H, Tello R, Infante R, Watts DM, et al. Strongyloides stercoralis hyperinfection associated with human T cell lymphotropic virus type-1 infection in Peru. Am J Trop Med Hyg. 1999;60(1): 146-9. https://doi.org/10.4269/ajtmh.1999.60.146.

\section{Publisher's Note}

Springer Nature remains neutral with regard to jurisdictional claims in published maps and institutional affiliations.

Ready to submit your research? Choose BMC and benefit from:

- fast, convenient online submission

- thorough peer review by experienced researchers in your field

- rapid publication on acceptance

- support for research data, including large and complex data types

- gold Open Access which fosters wider collaboration and increased citations

- maximum visibility for your research: over $100 \mathrm{M}$ website views per year

At BMC, research is always in progress.

Learn more biomedcentral.com/submissions 